\title{
Technologies to mitigate enviromental impact of swine production
}

\section{C.M. (Mike) Williams}

Director - Animal and Poultry Waste Management Center, North Carolina State University, Box 7608, 2711 Founders Drive, Raleigh, North Carolina 27695-7608, USA

\section{Introduction}

Over 90 million metric tons of pork is produced globally on an annual basis (USDA, 2008). Consumption and, thus, production of pork will likely continue o increase relative to the world's population and economy. During the past two decades worldwide trends in pork production have been towards industrial systems, e.g. systems in which none or a very low percent of the feed for the animals is produced within the production (or farm) unit. Such systems are generally based on large economies of scale and production efficiency is high relative to units of feed or man-hour inputs. Such systems have been shown to be very effective at producing an escalating demand for affordable meat products. However, the impact of livestock production on the environment as well as human health effects attributed to production and how producers and agribusiness deal with those impacts, especially in a global based economy, are significant issues that will determine the future of the pork industry in many parts of the world.

Environmental issues associated with the production of pork are geographically specific but, in general, include: land application manure by-products including nitrogen, phosphorus, potassium, heavy metals (e.g. $\mathrm{Cu}$ and $\mathrm{Zn}$ ); the discharge of these nutrients and pathogenic bacteria to surface and groundwater; production-associated consumption of limited water resources; and aerial emissions of volatile organic compounds, ammonia, hydrogen sulphide, dust (particulates), pathogens and odor.

In the USA, North Carolina represents a state and region in which much pork production activity has occurred over the past two decades and serves as a model for 1) the rapid growth of the industry, 2) identification of issues (environmental, social, and political) related to the rapid growth of the industry, and 3) efforts to develop new environmental management technology to address these issues. Between 1991 and 1997 the day-to-day inventory of swine in the state increased by approximately 300\% from 2.7 million head to approximately 10 million head. During this same period, the number of swine production facilities declined, while large, intensive operations growing thousands of animals in confined areas greatly expanded. However, beginning in 1970 the number of production facilities has decreased by $90 \%$ from 20,000 to approximately 2,000 facilities (North Carolina Department of Environment and Natural Resources, 2000). However, since 1997 the number of facilities and the number of animals has remained stable due, in part, to a state mandated moratorium on new facilities that utilize traditional swine waste management treatment processes. Expansion of the industry can only occur with the implementation of "innovative" or "Environmentally Superior Technologies".

This paper focuses on environmental issues and efforts and challenges to develop innovative waste management technologies to mitigate current and future environmental concerns. Particular focus is devoted to a North Carolina project to develop "Environmentally Superior Technologies”.

\section{Environmental issues}

The lagoon (or "effluent pond") waste treatment system provides for biochemical oxygen demand (BOD) reduction during the anaerobic treatment process and nutrient uptake by subsequent crop assimilation when the treated effluent is land applied (ASAE, 1993).

Advantages of this system include ease of operation and effective manure management for many environmental variables; however, concerns include 
potential groundwater impacts and system failure due to excessive rainfall. In addition, concerns have been identified associated with aerial emissions of compounds such as ammonia, hydrogen sulphide, greenhouse gases, volatile organic compounds, and particulate matter (Williams, 2002).

\section{Ground and surface water issues}

The risk of groundwater contamination by manure nutrients and pathogens is related to lagoon construction, spray field management, soil and geologic conditions, and climate. A study in North Carolina showed evidence of leaching from some clay-lined lagoons (North Carolina Department of Environment and Natural Resources, 1998). However, the study noted that due to the small sample number only limited conclusions could be drawn concerning the adequacy of the lagoon construction standards and the validity of the groundwater vulnerability assessment. Subsequently, Huffman (1999) reported results for a study designed to determine the extent to which animal waste lagoons pose a threat to groundwater. This study focused on swine waste lagoons that were constructed prior to restrictive lagoon construction requirements. The results showed that of 34 lagoon site assessments, one third of the sites met USA Environmental Protection Agency drinking water standards for nitrate at 38.1 metres from the lagoon (review boundary) and two thirds met the standard at 76.2 metres (compliance boundary). Collectively these studies indicate that lagoons can impact groundwater under certain environmental conditions.

Direct discharge to surface waters from a lagoon system failure when such incidents occur is no doubt a serious environmental hazard. Burkholder (1997) reported the impacts from one such event in which approximately 75 million liters of lagoon effluent was released when the earthen lagoon containment ruptured. Such catastrophic events, however, are very infrequent. Accumulated nutrient loading and aerial emissions associated with permitted waste management systems within a geographical region containing intensive animal agriculture operations is more likely to be a long term environmental concern relative to ground and surface waters within the region.

\section{Nutrient loading issues}

Nutrient loading within a geographical region impacts the diversity and productivity of living organisms within that region (Gundersen, 1992). Grain is often imported for animal feed into regions where animals are produced in high numbers. Excreted nutrients in manure by-products are usually managed and applied onto land near the facilities in which the animals are produced. Under these conditions, nutrient imbalances are likely, and adverse environmental impacts may occur when land application of manure nutrients exceeds crop utilization potential, or if poor management is used during the manure application, resulting in nutrient loss due to environmental factors such as soil erosion or surface runoff during rainfall.

Nitrogen in the manure is influenced by management practices used to treat the waste and may:

- be removed by crop harvest,

- leave the animal production facility, or application field as a gas $\left(\mathrm{NH}_{3}, \mathrm{NO}, \mathrm{NO}_{2}\right.$, $\mathrm{N}_{2} \mathrm{O}$ or $\mathrm{N}_{2}$ ) or,

- due to its mobility in soil, may be transported as organic or inorganic nitrogen forms in the liquid state via surface runoff or leaching into groundwater.

Groundwater contamination of $\mathrm{NO}_{3}-\mathrm{N}$, regardless of the $\mathrm{N}$ source, is a health risk when infants susceptible to methemoglobinemia, commonly referred to as "blue baby syndrome”, consume $\mathrm{NO}_{3}-\mathrm{N}$. Although serious, the frequency of this condition is rare. A more prevalent environmental impact from $\mathrm{NO}_{3}-\mathrm{N}$ is eutrophication of surface waters resulting in fish kills, increased aquatic weed growth, decreased subsurface plants and benthic organisms, and loss of aquatic biota diversity due to increased sedimentation and turbidity preventing normal sunlight penetration into the water column.

Unlike nitrogen, phosphorus is very immobile in soil and must be transported to a surface water environment to have an impact. Although, it has historically been accepted that phosphorus affects receiving waters via transport in eroding soil or in surface runoff as soluble inorganic or organic phosphorus, phosphorus leaching to shallow groundwater and lateral losses of phosphorus via export in subsurface runoff may be significant under certain soil conditions (Sims et al., 1998). Phosphorus, like N, contributes to environmental degradation by accelerating the process of eutrophication. The eutrophication threshold for most P-limited aquatic 
systems is very low, ranging from 10 to $100 \mu \mathrm{g} \mathrm{P}$ per litre (Mason, 1991). Another potential negative, although indirect, effect that has been reported from excess nitrogen and phosphorus in surface water is the formation of carcinogenic trihalomethanes (Palmstrom et al., 1988). Trihalomethanes are carcinogenic and result from the chlorination of eutrophic waters that are to be used for drinking water supplies. This illustrates how excessive nutrient loading to ground and surface waters can have undesirable impacts on human health as well as on the aquatic ecosystem.

\section{Aerial emission issues}

Aerial emissions from animal facilities are a major emerging issue for many parts of the world. Aerial pollutants of concern, which may be emitted from pork production facilities, include ammonia, hydrogen sulfide, methane, nitric oxide, nitrous oxide, volatile organic compounds (VOCs), odorants and particulate matter. In addition, pathogenic bacteria and bacterial products such as endotoxins and exotoxins may also be emitted from concentrated animal feeding operations (Williams, 2002). For many pork operations emissions of nitrogen are the compounds of primary concern. Nitrogen is a component element of proteins, nucleic acids, and other important bio-molecules necessary for life. However, waste products of nitrogen metabolism excreted in swine waste are predominately in the form of organic nitrogen and under the biological treatment or storage conditions of most waste management practices, it is rapidly converted to ammonia $\left(\mathrm{NH}_{3}\right)$. The amount of ammonia that is actually emitted into the atmosphere, however, is dependent upon many variables including climate, the animal housing design, manure storage and treatment facilities, as well as waste management treatment strategies and methods employed for land application of manure.

Numerous studies have been conducted worldwide to determine emission compounds and emission rates of those compounds from animal operations. However, a recent report by the USA National Academy of Sciences concluded that the published scientific literature is inadequate to establish definitive emission estimates (e.g. emission factors) for animal production operations ${ }^{1}$. The seriousness of this matter is well illustrated in current published data. For example, using swine as a model, reported values of excreted nitrogen in fresh swine manure, as Total Kjeldahl nitrogen (organic nitrogen + ammonia) and ammonia nitrogen, are 0.52 kilograms (kg) and $0.29 \mathrm{~kg}$, respectively, per $1000 \mathrm{~kg}$ live animal mass per day (ASAE, 2001). Utilizing these values, it is calculated that up to approximately 13 kilograms of ammonia are capable of being produced per pig-finishing space per year. Published data shows that emissions from swine buildings and waste treatment facilities can vary significantly reported building emissions range from approximately 1 to 6 grams $\mathrm{NH}_{3} /$ day/pig and approximately 0.2 to $5 \mathrm{~kg}$ $\mathrm{NH}_{3} /$ year/pig space (Williams, 2002).

It will be necessary in the future for the scientific and regulatory community to develop much better scientific methodologies, if the objective is to establish accurate assessments of the air quality impacts from pork and other livestock production facilities. Such an effort would be beneficial not only regarding the appropriate requirements according to regional, state, country, or international policy, but also for determining the effectiveness of various technologies currently available or under development that focus on emission abatement strategies. Such refinement needs to reflect subclasses within animal species, dietary variation, building design, and waste treatment system options selected or designed to abate ammonia emissions. Currently, a "National Air Emission Monitoring Study," conducted under the advisement of the U.S. Environmental Protection Agency, is underway to record two continuous years of emission data at concentrated animal feeding operations (NAEMS, 2008). Such studies will help provide much needed objective emissions data.

Dust and odor emissions generated at animal production facilities are another emerging environmental issue of particular importance, especially because of the potential impacts that these components have on human health. There is little doubt that dust emissions contain microorganisms and other materials (e.g. bacteria, endotoxins, viruses, molds, as well as

\footnotetext{
${ }^{1}$ See Final Report: Air Emissions from Animal Feeding Operations: Current Knowledge, Future Needs. Published on Web-Site http://books.nap.edu/books/0309087058/html/R1.html (2003).
} 
odorants) that can impact animal and human health. The primary question is the extent to which these emissions impact, not only farm workers, but also the neighbours of production facilities. A review of the scientific literature indicates that there are valid concerns regarding the health impacts on farm workers who are involved with the day-to-day production activities, but there is also much uncertainty regarding the impact that dust and odor have on surrounding neighbours (Schiffman et al., 2000). As previously noted for the development of science based emission factors, there is also a strong need to design and conduct objective studies regarding the impact of livestock operations on human health.

\section{Technology development for future swine waste management systems}

The attention that is directed to the development of new animal waste treatment technology involves academic institutions and the private sector, including the animal production industry. On a global scale, there are several countries that have been very active in researching animal manure management related issues. Historically, research projects have covered a variety of concerns with most technological research occurring in the laboratory with very limited commercial or pilot scale evaluations complete or in place.

In some areas of the world, there has been greater focus on dairy and poultry production concerns. However, most researchers are focusing on systems integration, performance of alternative manure handling technologies and the development and market demand for value-added products resulting from the new technologies. Unfortunately, there is limited economic data being generated, especially concerning the environmental impacts associated with livestock production and manure management alternatives. In 1997, 15 experienced researchers from 11 countries, mostly in Western Europe, published a study regarding manure treatment strategies (Silsoe Research Institute, 1997). The authors defined the "state of the art" of animal manure management and concluded that a range of treatments are already available that can address many of the identified environmental issues. Available treatments included aeration, anaerobic digestion including lagoons, solids separation, and composting. New processes that were identified as potentially effective included thermal treatments, purification by soil, use of chemical additives, and membrane processes. However, it was also concluded that if the use of manure is to be other than direct land application as a source of plant nutrients, there are economic challenges to developing commercially competitive value-added products. This remains a universal challenge and the practicality of applying many alternative technologies is largely unproven at the present time. The present level of research, development, and demonstration efforts, however, provides optimism that alternatives may be developed and proven practical in the future.

\section{Environmentally Superior Technologies - performance verification and economic assessment efforts in North Carolina}

Agreements between the Attorney General of North Carolina and Smithfield Foods (Smithfield), Premium Standard Farms (PSF), and Frontline Farmers ${ }^{2}$ provided resources for the identification, development, environmental performance verification, economic feasibility analysis, and demonstration of candidate “Environmentally Superior Technologies" (EST). Performance standards defined in the Agreements mandated that successful EST address environmental variables including the discharge of animal waste to surface waters and groundwater; emission of ammonia; emission of odor; release of disease-transmitting vectors and airborne pathogens; and nutrient and heavy metal contamination of soil and groundwater. Comprehensive determinations of economic feasibility were also mandated by the Agreements. Targeted economic variables include projected 10-year annualized cost for each technology; projected revenues from by-product utilization; available cost-share monies; and the impact

\footnotetext{
2 See Agreements between Attorney General of North Carolina and, SF, PSF, and Frontline Farmers (North Carolina Department of Justice, 2000 \& 2002). Also available at www.cals.ncsu.edu/waste_mgt/
} 
that the adoption of the EST may have on the competitiveness of the North Carolina pork industry as compared to the pork industry in other areas.

Selection of EST candidates to undergo performance verification and economic analysis involved a request for proposals that was issued nationwide to research institutions and industry. Selections were based on terms and conditions of the Agreements and competitive review. Collectively, this process yielded 18 EST candidates. Subsequently, most of the candidate EST were studied on commercial scale site locations in eastern North Carolina or on pilot scale NCSU laboratory or research farm sites. Detail reports describing this initiative and results have been published (Williams, 2004, 2005, 2006, 2007).

Swine waste treatment technology studied under these Agreements included a covered in-ground anaerobic digester, a sequencing batch reactor, an upflow biological aerated filter system, mesophilic and thermophilic anaerobic digesters, energy recovery systems, greenhouse vegetable production system, solid separations systems, constructed wetlands system, nitrification-denitrification systems, soluble phosphorus removal systems, belt manure removal systems, gasification system to thermally convert dry manure to a combustible gas stream for liquid fuel recovery, manure solids conversion to insect biomass for value-added processing into animal feed protein meal and oil system, reciprocating water technology system, and a dewatering / drying / desalinization system.

As previously noted each candidate technology was assessed for technical, operational, and economic feasibility. Environmental performance analysis for these technologies included an integrated program approach in which each was systematically analyzed for emissions of odor (Schiffman et al., 2003), pathogens (Sobsey et al., 2003) and ammonia (Aneja et al., 2003). In addition, a full economic assessment was conducted for each technology (Murray et al., 2003; Wohlgenant et al., 2003). As such, a model decision tool framework was developed to identify viable technologies based on measured performance data. The environmental model integrates waste residuals reductions (e.g. odor, aerial ammonia, particulates, total nitrogen and phosphorus that is land applied) to cost benefits.

A comprehensive Phase 3 Report summarizing results was published (Williams, 2006). Examples of environmental performance data reflected in that and the previously referenced 2004 Phase 1 and 2005 Phase 2 reports are shown in Table 1. Examples of the economic analysis data are shown in Table 2 . Subsequent to the Phase 3 Report findings one of the targeted systems, the so called Super Soil Systems "Second Generation" technology was designed and developed with the primary objective to reduce its costs while maintaining its capability to meet technical (environmental) standards. The cost data shown in Table 2 for the "Super Soils" system reflect the economic analysis of the "second generation” effort (Williams, 2007).

\section{Conclusions and future perspective}

The growth of the swine industry in North Carolina and associated issues represents a model of scientific, social, and political challenges regarding environmental impacts and health effects attributed to the swine industry worldwide regarding production and waste management practices. The results referenced herein show that new and innovative waste treatment technologies can address identified environmental impacts, however, such technologies are currently not widely employed on swine production facilities in North Carolina or elsewhere. Issues which will determine the future of the swine industry in many parts of the world include 1) objective determination of environmental impacts and potential human health effects that can be attributed to the production of swine, 2) the ability of the industry to respond and adapt to new environmental rules that will be mandated upon animal producers in the future by government entities, and 3) the ability of the industry to develop and, more importantly, to implement new and innovative waste treatment technologies in a manner that is economically feasible for producers.

The comprehensive findings provided herein also show that organized efforts to reduce the costs of 
technologies to mitigate environmental impacts of swine production are achievable. This work supports previous recommendations to identify potential institutional incentives and policies that will reward farmers for utilizing technologies identified that are shown to yield improvements and environmental benefits over current waste treatment systems. It is recommended that the optimal method of achieving net cost reductions from alternative technologies is to install targeted technologies on a sufficient number of farms to facilitate engineering improvements, value-added product market development, and other cost reduction methods.

Table 1 - Examples of environmental performance data published to date for the candidate "Environmentally Superior Technologies" (see referenced 2006 Phase 3 Report for detail data for all systems).

\begin{tabular}{|c|c|c|}
\hline System & Parameter & Value \\
\hline $\begin{array}{l}\text { Ambient digester / } \\
\text { Greenhouse tomato } \\
\text { production } \\
\text { (“Barham Farm”) }\end{array}$ & $\begin{array}{c}\text { COD } \\
\text { Solids } \\
\text { Ammonia } \\
\text { Energy } \\
\text { produced - } \\
\text { winter } \\
\text { Energy } \\
\text { produced - } \\
\text { summer } \\
\text { Marketable } \\
\text { tomatoes } \\
\text { Pathogens } \\
\text { Odor - 400m } \\
\text { from source }\end{array}$ & $\begin{array}{c}93 \% \text { reduction } \\
76-88 \% \text { reduction } \\
29 \% \text { reduction } \\
\text { (trickling filter) } \\
560 \mathrm{kWh} / \text { day } \\
990 \mathrm{kWh} / \text { day } \\
711 \mathrm{~kg} / \text { day } \\
2.8-5.2 \text { Log10 } \\
\text { reductions } \\
1.4 \text { of } 8 \text { intensity ( } 8= \\
\text { max) }\end{array}$ \\
\hline $\begin{array}{c}\text { Solids separation/ } \\
\text { nitrification, } \\
\text { denitrification/ } \\
\text { Phosphorus removal } \\
\text { (“Super Soils”) }\end{array}$ & $\begin{array}{c}\text { COD } \\
\text { Solids } \\
\text { Ammonia } \\
\text { Phosphorus } \\
\text { Pathogens } \\
\text { Odor - 200m } \\
\text { from source } \\
\text { Odor - 400m } \\
\text { from source }\end{array}$ & $\begin{array}{c}97 \% \text { reduction } \\
98-99 \% \text { reduction } \\
99 \% \text { reduction } \\
95 \% \text { reduction } \\
1.4-4.4 \text { Log10 } \\
\text { reductions } \\
2.1 \text { of } 8 \text { intensity ( } 8= \\
\text { max) } \\
1.3 \text { of } 8 \text { intensity ( } 8= \\
\text { max) }\end{array}$ \\
\hline Belt manure removal & $\begin{array}{c}\text { NH3 emitted per } \\
\text { pig space }\end{array}$ & 1 kg/year (projected) \\
\hline $\begin{array}{l}\text { Solids Separation - } \\
\text { Reciprocating } \\
\text { Wetland }\end{array}$ & $\begin{array}{c}\text { COD } \\
\text { Solids } \\
\text { Ammonia } \\
\text { Pathogens } \\
\text { Odor - 200m } \\
\text { from source } \\
\text { Odor - 400m } \\
\text { from source }\end{array}$ & $\begin{array}{c}83 \% \text { reduction } \\
48-94 \% \text { reduction } \\
88 \% \text { reduction } \\
0.7-1.8 \text { Log10 } \\
\text { reductions } \\
2.8 \text { of } 8 \text { intensity }(8= \\
\text { max) } \\
2.0 \text { of } 8 \text { intensity }(8= \\
\text { max) }\end{array}$ \\
\hline
\end{tabular}

Table 2 - Examples of economic analysis data published to date for the candidate "Environmentally Superior Technologies" (see referenced 2006 Phase 3 Report for detail data for all systems).

\begin{tabular}{|c|c|c|}
\hline System & $\begin{array}{c}10 \text { year } \\
\text { annualized cost } \\
\text { (\$ per } 1000 \text { lbs. } \\
\text { steady state live } \\
\text { weight per year) }\end{array}$ & $\begin{array}{l}\text { Estimated change } \\
\text { (percent reduction) in } \\
\text { predicted North Carolina } \\
\text { market hog quantities } \\
\text { (1,000 lbs. of weight } \\
\text { marketed) in the long run } \\
\text { for the annualized cost } \\
\text { metric shown (assuming } \\
\text { mandated } \\
\text { implementation of the } \\
\text { technology system) }\end{array}$ \\
\hline $\begin{array}{l}\text { Ambient digester / } \\
\text { Greenhouse tomato } \\
\text { production } \\
\text { ("Barham Farm") }\end{array}$ & $\$ 89$ & $12 \%$ \\
\hline $\begin{array}{c}\text { Solids separation/ } \\
\text { nitrification, } \\
\text { denitrification/ } \\
\text { Phosphorus removal } \\
\text { ("Super Soils” } \\
\text { Second Generation } \\
\text { system) }\end{array}$ & $\$ 300$ & $43 \%$ \\
\hline Belt manure removal & $\$ 89$ & $12 \%$ \\
\hline $\begin{array}{c}\text { Solids Separation - } \\
\text { Reciprocating } \\
\text { Wetland }\end{array}$ & $\$ 143$ & $21 \%$ \\
\hline
\end{tabular}

\section{References}

Aneja, V., Kim, D., Arya, P., Robarge, W., Todd, L., Dickey, D., Stefansky, L., Williams, M., Arkinson, H., Semunegus, H., Bajwa, K., Rumsey, I., and Holmes, Z. (2003). An evaluation of the emissions of ammonia from four potential environmentally superior technologies for swine facilities: Barham, Corbett \#2, and Howard Farms, and Grinnells Laboratory. (2003). Proceedings North Carolina Animal waste Management Workshop. Oct. 16-17, 2003, Research Triangle Park, NC. Edited by G.B. Havenstein. Published by College of Agriculture and Life Sciences, NCSU, Raleigh, NC. Pages 91-101.

ASAE - American Society of Agricultural Engineers. (1993). Design of anaerobic lagoons for animal waste management, Standard EP403.2 p 543-546.

ASAE - American Society of Agricultural Engineers. (2001). Manure Production Characteristics, Standard D384.1.

Burkholder, J., Mallin, M., Glasgow, H., Larsen, L., McIver, M., Shank, G., Deamer-Melia, N., Brimley, D., Springer, J., Touchette, B., and Hannon, E. (1997). Impacts to a coastal river and estuary from rupture of a large swine waste holding facility. J. Environ. Qual. 26:1451-1466.

Gundersen, P. (1992). Mass balance approaches for establishing critical loads for nitrogen in terrestrial ecosystems, in Proceedings of a Workshop in Lockeberg, Sweden 56-81 (Nordic Council of Ministers Report, Copenhagen, Denmark. 
Huffman, R. (1999). Groundwater impacts of lagoons. North Carolina State University college of Agriculture and Life Sciences, on file with Rodney Huffman.

Mason, C. (1991). Biology of freshwater pollution, 2nd Ed., Wiley, New York, New York.

Murray, B., Van Houtven, G., Deerhake, M., Dodd, R., Lowry, M., Yao, C., Miles, A., Phaneuf, D., Sommer, A., Cajka, J., Coburn, J., and Patil, S. (2003). Economic feasibility assessment of the Smithfield Foods Agreement environmental modeling and benefits components. Proceedings North Carolina Animal Waste Management Workshop. Oct. 16-17, 2003, Research Triangle Park, NC. Edited by G.B. Havenstein. Published by College of Agriculture and Life Sciences, NCSU, Raleigh, NC. Pages 126-139.

NAEMS (National Air Emissions Monitoring Study). (2008) See http://cobweb.ecn.purdue.edu/ odor/NAEMS/updates.htm

North Carolina Department of Environment and Natural Resources. (1998). Impact of animal waste lagoons on groundwater quality, on file with A. Mouberry.

North Carolina Department of Environment and Natural Resources. (2000). Framework for the conversion of anaerobic lagoons and sprayfields - technology panel final report, on file with Dennis Ramsey.

Palmstrom, N., Carlson, R., and Cooke, G. (1988). Potential links between eutrophication and formation of carcinogens in drinking water. Lake Preserv Manage 4:1-15.

Schiffman, S., Walker, J., Dalton, P., Lorig, T., Raymer, J., Schusterman, D., and Williams, M. (2000). Potential health effects of odour from animal operations, waste water treatment, and recycling of by-products. J. of Agromedicine 7:7-81.

Schiffman, S., Graham, B., McLaughlin, B., Fitzpatrick, D., Katul, G., Nagle, T., and Williams, M. (2003). Predicting odour dispersion at five swine facilities using a EulerianLagrangian model. Proceedings North Carolina Animal waste Management Workshop. Oct. 16-17, 2003, Research Triangle Park, NC. Edited by G.B. Havenstein. Published by College of Agriculture and Life Sciences, NCSU, Raleigh, NC. Pages 102-111.

Silsoe Research Institute (1997). Manure Management Treatment Strategies for Sustainable Agriculture (C.H. Burton ed. Silsoe Research Institute, Wrest Park, Silsoe, Bedford, UK.

Sims, J., Simard, R., and Joern, B. (1998). Phosphorus loss in agricultural drainage: historical perspective and current research. J. Environ. Qual. 27:277-293.
Sobsey, M., Gwangpyo, K., Simmons, O., Likirdopulos, C., and Worley-Davis, L. (2003). Evaluation of alternative swine waste treatment and management technologies for control of pathogens. Proceedings North Carolina Animal waste Management Workshop. Oct. 16-17, 2003, Research Triangle Park, NC. Edited by G.B. Havenstein. Published by College of Agriculture and Life Sciences, NCSU, Raleigh, NC. Pages 112-125.

USDA. (2008). Foreign Agricultural Statistics. http://www.fas.usda.gov/currwmt.asp

Williams, C.M. (2002). CAFOs: issues and development of new waste treatment technology. Penn State Envir. Law Rev. 10(2):217-247.

Williams, C.M (2004). Development of Environmentally Superior Technologies. 2004. Phase 1 Technology Determination Report, published by NCSU College of Agriculture and Life Sciences, 941 pgs, on file with NCSU Animal and Poultry Waste Management Center (July 26, 2004). Also available at www.cals.ncsu.edu/waste_mgt/

Williams, C.M. (2005). Development of Environmentally Superior Technologies. 2005. Phase 2 Technology Determination Report, published by NCSU College of Agriculture and Life Sciences, 1428 pgs, on file with NCSU Animal and Poultry Waste Management Center (July 25, 2005). Also available at www.cals.ncsu.edu/waste_mgt/

Williams, C.M. (2006). Development of Environmentally Superior Technologies. 2006. Phase 3 Technology Determination Report, published by NCSU College of Agriculture and Life Sciences, 716 pgs, on file with NCSU Animal and Poultry Waste Management Center (March 8,2006). Also available at www.cals.ncsu.edu/waste_mgt/

Williams, C.M (2007). Development of Environmentally Superior Technologies. 2007. Phase 1 Environmentally Superior Technology Contingent Determinations. Second Generation Super Soils Technology, published by NCSU College of Agriculture and Life Sciences, 133 pgs, on file with NCSU Animal and Poultry Waste Management Center (November 1, 2007). Also available at www.cals.ncsu.edu/waste_mgt/

Wohlgenant, M., Zering, K., Vukina, T., Chvosta, J., Marra, M., Renkow, M., Wossink, A., Muth, M., and Murray, B. (2003). Economic feasibility assessment of the Smithfield Foods Agreement: costing of alternative waste management technologies and modeling effects on North Carolina pork industry components. Proceedings North Carolina Animal waste Management Workshop. Oct. 16-17, 2003, Research Triangle Park, NC. Edited by G.B. Havenstein. Published by College of Agriculture and Life Sciences, NCSU, Raleigh, NC. Pages 140-149. 